commentary to the Law of Ukraine On Environmental Protektion] N.R. Malysheva, M.I. Yerofeiev. Kharkiv: "Pravo". 2017. 417 s. (in Ukrainian) 20. Pohrebniak, S.P. (2015). Rozdil 12. Pryntsypy prava [Section 12 Principles of law] / Teoriia derzhavy i prava [Theory of state and law] / O.V. Petryshyn, S.P. Pohrebniak, V.S. Smorodynskyi ta in.; za red. O.V. Petryshyna. Kharkiv: "Pravo". S. 123 - 133 (in Ukrainian).

21. Pozniak, E.V. (2013). Pryntsyp ekosystemnosti v ekolohichnomu pravi: poniattia ta zmist [The principle of ecosystems in environmental law: concept and content ]. Visnyk Kyivskoho natsionalnoho universytetu imen Tarasa Shevchenka. Yurydychni nauky [Bulletin of Taras Shevchenko National University of Kyiv. Legal sciences]. Vyp. 4 (98). S. $39-42$ (in Ukrainian).

22. Pozniak, E.V. (2016). Teoretyko-pravovyi zmist pryntsypu formuvannia ekolohichnoi kultury $v$ Ukraini [Theoretical and legal content of the principle of formation of ecological culture in Ukraine]. Aktualni problemy yurydychnoi nauky [Actual problems of legal science] (s. 38 - 40) Khmelnytsky University of Management and Law (in Ukrainian).

23. Pravova kultura $v$ umovakh stanovlennia hromadianskoho suspilstva [Legal culture in the conditions of formation of civil society] / Za red. prof. Yu.P. Bytiaka ta dots. I.V. Yakoviuka. Kharkiv: "Pravo" (2007) (in Ukrainian).

24. Spiridonov, L.I. (1996). Teoriya gosudarstva i prava [Theory of the state and law]. Moskva: "Status LTD+" (in Russian).

E. Pozniak, Cand. Sc. (Law), Associate Prof., psychologist

Taras Shevchenko National University of Kyiv, Kyiv, Ukraine
25. Suietnov, Ye.P. (2020). Do pytannia pro vyznannia ekosystemnoho pidkhodu kvintesentsialnym pryntsypom ekolohichnoho prava [On the question of recognizing the ecosystem approach as the quintessential principle of environmental law]. Problemy zakonnosti [Problems of legality]. Vyp. 149. S. $92-113$ (in Ukrainian).

26. Teoriia derzhavy i prava [Theory of the state and law] A.M. Kolodii, V.V. Kopieichykov, S.L. Lysenkov ta in.; Za zah. red. S.L. Lysenkova, V.V. Kopieichykova. Kyiv: "Yurinkom Inter" (in Ukrainian).

27. Chausova, L.L. (1998). Pryntsypy ekolohichnoho prava [Principles of Ecogical law] [avtoreferat dysertacii kand. juryd. nauk]. Natsionalna yurydychna akademiia Ukrainy im. Yaroslava Mudroho [Yaroslav Mudryi National Legal Academy of Ukraine], Kharkiv (in Ukrainian).

28. Shemshuchenko, Yu.S. Rozdil 1. Ekolohichne pravo - kompleksna haluz prava [Ecogical law is a complex branch of law] / Ekolohichne pravo Ukrainy. Akademichnyi kurs [Ecogical law of Ukraine. Academic course] / Za red. Yu.S. Shemshuchenka. Kyiv: "TOV "Vydavnytstvo «lurydychna dumka»" (2008). S. 8 - 26 (in Ukrainian).

Received: $27 / 07 / 2021$ Accepted: $28 / 08 / 2021$

\title{
THE PRINCIPLE OF ECOLOGICAL CULTURE FORMATION IN UKRAINE: PROBLEMS OF THEORETICAL AND LEGAL CONTENT AND PROSPECTS OF DEVELOPMENT
}

The article examines the theoretical and legal, legislative and other approaches to understanding the essence and content of the principle of formation of ecological culture in environmental law and legislation of Ukraine. At present, the principle of formation of ecological culture is only partially reflected in the norms of the Constitution of Ukraine and current legislation, in particular the Law of Ukraine "On Environmental Protection".

The implementation of this principle in legislative, practical and law enforcement activities will help increase the level of environmental and legal awareness and culture, ecologization of national law and legislation. The level of ecological and ecological-legal culture in society determines the effectiveness of operation of ecological management and control system, the guarantee of the ecological safety of economic and other activities, the achievement of ecological law and order, the restoration of ecological balance, the development of science and ecological knowledge.

The strengthening of the principle of ecological culture formation will be promoted by performance of the strategic tasks put in provisions of sources of the state ecological policy, primarily, the Basic principles (strategy) of the state ecological policy for the period till 2030.

Proposals have been made to improve the current legislation in order to take into account the principle of forming an environmental culture, guaranteeing the sustainable development of our country from the standpoint of current challenges and processes of globalization. The opinion on the expediency of constitutional contemplation of the principle of formation of ecological culture as a basis for building a democratic, social, legal and ecological state had been expressed. This principle is offered to supplement the main sources of natural resources, environmental law and environmental safety law.

The introduction of the principle of formation of ecological culture in the national legislation should assume a nature of a systemic character, which will help to provide the coherence of environmental law and other branches in the regulation of environmental relations. This will increase the level of ecological and legal culture of society and citizens and strengthen the course of our state towards international and European integration.

Keywords: ecological culture, ecological-legal culture, ecological law, ecological legislation, environment, principles of ecological law, principles of law, state ecological policy.

Bulletin of Taras Shevchenko National University of Kyiv.

Legal Studies, 2021; 3 (118): 99-105

УДК $347.91 / 347.95$

DOI: https:doi.org/10.17721/1728-2195/2021/3.118-18
ISSN 1728-2195

(C) Taras Shevchenko National University of Kyiv,

Publishing center "Kyiv University", 2021

Ю. Д. Притика, д-р юрид. наук, зав. каф. ORCID ID: 0000-0001-5992-1144,

I. O. Ізарова, д-р юрид. наук, проф. ORCID ID: 0000-0002-1909-7020

Київський національний університет імені Тараса Шевченка, Київ, Україна

\section{ФОРМУВАННЯ НАЦІОНАЛЬНОЇ ДОКТРИНИ ЦИВІЛЬНОГО ПРОЦЕСУ В РОБОТАХ НАУКОВЦІВ КИЇВСЬКОГО НАЦІОНАЛЬНОГО УНІВЕРСИТЕТУ IMEHI ТАРАСА ШЕВЧЕНКА В ПЕРІОД НЕЗАЛЕЖНОСТІ УКРАЇНИ}

Мета проведеного дослідження - установити внесок науковців-правників Київського національного університету імені Тараса Шевченка у розвиток доктрини науки цивільного процесуального права в період незалежності України, 3 1991 року. Для реалізації цієї мети застосовано наукові методи аналізу основних законодавчих актів, що регулюють цивільні процесуальні відносини, виокремлено й охарактеризовано положення тих досліджень, в яких було запропоновано нові підходи до вдосконалення механізму реалізації права особи на справедливий суд, забезпечення доступу до правосуддя в цивільних справах, розвиток і вдосконалення цивільного судочинства в умовах забезпечення сучасних міжнародних, зокрема європейських, підходів. Результатами проведеного дослідження виявлено більше 40 дисертаційних досліджень, що були захищені впродовж обраного періоду в Київському університеті, а також багато наукових досліджень, що істотно вплинули на розвиток національної традиції цивільного процесу. Підбито підсумки проведеного дослідження та визначено напрями подальшого розвитку наукових пошуків у сфері цивільного процесуального права України.

Ключові слова: цивільний процес, Україна, доступ до правосуддя, правова доктрина, Київський університет, Цивільний процесуальний кодекс України.

\section{ВСТУП}

Подія 30-річчя незалежності України [1] дає гарну можливість підбити проміжні підсумки, проаналізувати досягнення, здобуті на шляху розбудови незалежної демократичної держави, а також осягнути прорахунки, яких навряд чи можна було уникнути. Обставини, за яких наша держава знову здобула незалежність, зумовили складність цього завдання. Не дивно, що тільки через п'ять років було ухвалено Конституцію України [2], в якій закладено основні засади майбутнього розвитку - 
демократичність, верховенство права та доступ до правосуддя, у межах яких і здійснювалася подальша розбудова державницьких інституцій. Наша держава приєдналася до Ради Європи 1995 року [3] і ратифрікувала Конвенцію про захист прав людини й основоположних свобод [4] (далі - Європейської конвенції), що ознаменувала еволюційне приєднання до єдиної системи забезпечення верховенства права Активна підтримка діалогу з Радою Європи і втілення під час реформування національного законодавства рекомендацій Комітету Міністрів Ради Європи це засвідчують [5]. Зобов'язання 3 визнання та виконання рішень Європейського суду 3 прав людини [6] (далі - ЄСПЛ) спонукає нас до перегляду традиційних підходів здійснення правосуддя, реформування власної судової системи з метою ії̈ вдосконалення. Величезну роль у цьому відіграє правова наука, зокрема та ії частина, що пов'язана зі сфрерою здійснення правосуддя в цивільних справах, забезпеченням ефективного врегулювання цивільних спорів i здійснення цивільного судочинства.

Формулювання мети й об'єкта дослідження. Метою статті $€$ характеристика доробку науковців Київського національного університету імені Тараса Шевченка, які досліджували питання здійснення правосуддя в цивільних справах, а також визначення впливу запропонованих концепцій на розвиток доктрини доступу до правосуддя та цивільного судочинства в незалежній Україні, з'ясування перспектив подальших напрямів наукових пошуків із метою забезпечення майбутніх реформ цивільного процесуального законодавства України.

Методологія дослідження. Для реалізації зазначеної мети досліджено основні законодавчі акти, що регулюють цивільні процесуальні відносини, виокремлено й окремо проаналізовано положення тих досліджень, в яких було запропоновано нові підходи до вдосконалення механізму реалізації права особи на справедливий суд, забезпечення доступу до правосуддя в цивільних справах, розвиток і вдосконалення цивільного судочинства в умовах забезпечення сучасних міжнародних, зокрема європейських, підходів. 3 огляду на зазначене, проаналізовано дисертаційні дослідження, монографічні роботи, наукові статті, а також інші джерела - рекомендації Р€, документи ООН, підручники тощо.

\section{ОСНОВНА ЧАСТИНА}

У сучасному світі об'єднаних націй, в якому панує Загальна декларація прав людини та Європейська конвенція, верховенство прав людини є однією з найважливіших засад розвитку [7]. Відповідно концепція доступу до правосуддя як ключового елемента зазначеної засади має фундаментальне значення для розбудови демократичної правової держави [8]. Сучасна парадигма сталого розвитку вимагає навіть більш конкретизованої реалізації рівного доступу до правосуддя для всіх в умовах мирного інклюзивного та справедливого суспільства [9].

З 1990 років, із часу здобуття свої незалежності, Україна докладає зусилля для забезпечення належного виконання взятих на себе міжнародних зобов'язань. Принагідно згадати, що наша держава $є$ однією з 50 держав - засновниць Організації Об'єднаних Націй (далі - ООН) у 1945 році [10]. Справедливо, що нині державою проголошено підтримку Цілей сталого розвитку ООН [11].

Поступова реалізація Угоди про асоціацію України 3 $€ C$, що була підписана 2014 року [12], а також свідомо обраний суспільством євроінтеграційний вектор розвитку, зумовлюють необхідність реформування національного законодавства. Вивчення еволюції розвитку європейської наукової процесуальної думки і визначних проєктів, спрямованих на забезпечення доступу до правосуддя в Європі, зближення та гармонізація цивільного процесу, спонукають на пошук шляхів забезпечення верховенства права і в Україні.

Цивільне процесуальне право $€$ однією з основних галузей сучасного права, яким урегульовано відносини між судом та учасниками судового розгляду. Основну увагу зосереджено саме на цивільному судочинстві, яке дуже часто називають цивільним процесом, оскільки термінологічна відмінність цивільного судочинства та цивільного процесу полягає в розумінні його значення та суб'єктного складу відносин із розгляду та вирішення справи, а також виконання судового рішення. Зокрема, цивільне судочинство традиційно розглядають як установлений нормами цивільного процесуального законодавства порядок, згідно з яким суд та учасники процесу беруть участь у розгляді і вирішенні справи [13]. Цивільний процес варто визначити як сукупність різних форм захисту порушених, невизнаних або оспорюваних прав, свобод та інтересів фрізичних осіб, прав та інтересів юридичних осіб, інтересів держави, який включає цивільне судочинство, а також альтернативне вирішення спорів, зокрема, третейськими судами, за участю медіатора тощо.

Принагідно зауважити, що в європейській правовій доктрині частіше застосовується термін civil justice, який ближчий до терміну правосуддя в цивільних справах [14]. Такий термін підкреслює широке розуміння правосуддя та доступу до правосуддя, яке сьогодні $€$ загальновизнаною концепцією в світі.

Передусім, зміни до Конституції України, в якій 3 2016 року закріплено можливість законодавчого закріплення обов'язкового досудового порядку врегулювання спору (ст. 124), право кожного на професійну правничу допомогу (ст. 59) [2], нову редакцію Цивільного процесуального кодексу 2017 р., а також Закони "Про судоустрій і статус суддів" [16], "Про виконавче провадження" [17], "Про міжнародне приватне право" [18] та ін., які зумовлюють необхідність перегляду традиційних підходів, що панували у доктрині цивільного процесуального права України.

Сьогодні важливо усвідомлювати, що сучасна концепція доступу до правосуддя включає не тільки здійснення судочинства у справі та виконання судового рішення 3 метою захисту прав особи, але й досудове або позасудове вирішення спору, що здійснюється без участі суду шляхом спрямування сторін спору до примирення. Негативні наслідки безперешкодного доступу до правосуддя як доступу тільки до суду у будь-яких справах і зневага до досудового врегулювання спорів вже давно оцінені у світі.

Слід одразу зауважити, що традиційно юрисдикція судів в Україні відповідно до положень Конституції у її редакції 1996 року поширювалася на всі правовідносини, а досудове або позасудове врегулювання спорів не мало обов'язкового характеру. 2016 року до Конституції України внесено зміни і закріплено положення про можливість законодавчого визначення обов'язкового досудового порядку врегулювання спору [2], що стало еволюційним проривом розвитку альтернативного врегулювання в нашій державі. Досудове врегулювання спору до цього часу як обов'язкову процедуру законодавчо закріплено ще не було [20, 21, 22]. Водночас, варто погодитись, що у зв'язку із цим концепція правосуддя в Україні була істотно оновлена і сьогодні включає і досудове врегулювання спору.

Згідно із зазначеним, цілком справедливо приділити увагу аналізу наукового потенціалу досліджень науковців-правників Київського національного університету імені Тараса Шевченка (далі - Київського університету). Підходи, що пропонувалися науковцями, із часу проголошення незалежності України частково реалізувалися в чинному законодавстві і практиці національних судів, а також стали основою доктрини науки цивільного про- 
цесуального права. 3 огляду на це, дослідження науковців юридичного фракультету (нині - Інституту права) Київського університету становить науковий інтерес.

Наука цивільного процесу завжди активно розвивалася в стінах Київського університету. Однією з перших праць, в яких досліджуються проблеми цивільного процесу (у порівнянні з кримінальним) стала робота Дмитра Германовича Тальберга "Гражданский иск в уголовном суде или соединенный процесс" [22].

Окрему увагу варто приділити Якову Львовичу Штутіну, який працював у Київському університеті з 1939 по 1957 роки. Серед його робіт - кандидатська дисертація на тему "Оценка доказательств в советском гражданском процессе" (1949), лекції з радянського цивільного процесу (1954) [23-27], наукова стаття, присвячена проблемам реалізації права на пред'явлення позову тощо. Варто відмітити, що Я. Л. Штутін захистив докторську дисертацію на тему "Предмет доказывания в советском гражданском процессе" в Московському державному університеті 1964 року. Увага до інституту доказування не згасає в роботах науковців Київського університету досі, зокрема, у кількох докторських дисертаціях основна увага була зосереджена на питаннях визначення предмета доказування, правил доказування, особливостях окремих засобів доказування тощо [28-35].

Певні проблеми розвитку цивільного судочинства, пов'язані з розбудовою судової системи, розглядались у працях Дмитра Спиридоновича Сусла, який 1973 року захистив докторську дисертацію на тему "Розвиток органів правосуддя і їх діяльності в Україні у 1918-1972 рр.", зміст якої знайшов відображення у монографії "Історія суду Радянської України (1917-1967)" [36].

Серед відомих представників науки цивільного процесу Павло Петрович Заворотько, який приділяв увагу питанням виконання судових рішень [37]. Виконання судових рішень справедливо привертає увагу науковців Київського університету, зокрема, піднімалися питання щодо вдосконалення окремих інститутів виконавчого провадження [38]. Принагідно відмітити, що реформа системи виконання судових рішень в Україні триває й науковці університету активно досліджують проблеми вдосконалення виконавчого провадження в Україні [39-41].

Роботи Михайла Йосиповича Штефана стали вагомим внеском у розвиток вітчизняної науки цивільного процесуального права. Його підручник витримав кілька перевидань і став основним посібником для вивчення цієї дисципліни на початку століття [42-43]. Більшість праць М. Й. Штефана має фундаментальний характер, вони присвячені актуальним проблемам теорії цивільного процесуального права, реалізації права на судовий захист на різних стадіях цивільного процесу, інституту судових рішень [44].

Разом із тим, можна сказати, що в 1990 роках увагу науковців Київського університету було зосереджено на більш прикладних дослідженнях, що видається цілком зрозумілим 3 огляду на складний процес становлення конституційних засад здійснення правосуддя, організації судової влади, трансформацію основних принципів судочинства тощо [45-50]. Увагу науковців Київського університету привертали також особливості розгляду окремих категорій справ у порядку цивільного судочинства [51-59].

Водночас, ухвалення Конституції України 1996 року, зростання ролі європейського права - права Ради Європи, а також практики ЄСПЛ, позначилося і на зміні підходів до наукових напрацювань, у фокусі уваги з'явилися інститути цивільного процесуального права, які потребували якісного переосмислення та реформування [60-64].

Прийняття нового ЦПК незалежної України 2004 року [65-72], а також його нової редакції у 2017 році [73-
76] стало поштовхом до активних досліджень питань цивільного процесуального права та аналізу практики застосування цивільного процесуального законодавства науковцями Київського національного університету імені Тараса Шевченка.

Варто відмітити, що впродовж останніх десятиліть істотно зростає науковий інтерес до питань, пов'язаних із позасудовим урегулюванням спорів [77], медіації [78], третейського розгляду [79].

Аналіз наукових праць представників школи Київського університету показує, що увага приділяється питанням основних інститутів цивільного процесуального права; водночас, недостатньо уваги надається питанням альтернативних способів вирішення спорів, майже відсутні порівняльно-правові дослідження, дослідження з історії цивільного процесу, міжнародного цивільного процесу, європейського цивільного процесу та гармонізації цивільного процесуального права у світі.

Останній напрям видається особливо важливим 3 огляду на вимоги чинного законодавства про адаптацію та наближення до права ЄС, вимоги Угоди про асоціацію тощо [80].

Створення 2020 року кафедри цивільного процесу в Інституті права зумовило активізацію наукових досліджень сучасних проблем цивільного процесу [81-85].

\section{ВИСНОВКИ}

Сьогодні варто особливо акцентувати увагу на необхідності належної реалізації в Україні концепції права кожного на справедливий суд, що гарантоване Європейською конвенцією, а також підвищити увагу до позасудового врегулювання спорів, що опосередковують право особи на доступ до правосуддя й ефективний захист своїх прав і свобод у сучасному світі. Важливо усвідомити загальносвітову тенденцію розвитку примирення сторін як найефективнішого врегулювання спорів і поширення різноманітних способів, які дозволяють сторонам знайти найбільш зручний і дієвий порядок захисту своїх прав.

Еволюційні зміни парадигми розвитку українського суспільства, а також національного законодавства, засвідчують необхідність удосконалення існуючої доктрини, а також практики викладання цієї дисципліни майбутнім юристам, зокрема, збільшення практичної складової їхнього навчання, що спрямована на забезпечення високого рівня професійної кваліфікації у майбутньому та конкурентоспроможності на ринку праці.

Видається необхідним також активізувати увагу на можливостях вивчення досвіду провідних держав світу, досягнень гармонізації й уніфрікації цивільного процесу в Європі, поглибленого вивчення підходів і практики, які можуть стати корисними під час подальшого реформування національного законодавства України.

Список використаних джерел

1. Декларація про державний суверенітет України. Постанова Верховної Ради УРСР від 16.07.1990 № 55-XII. URL: https://zakon.rada.gov.ua/ laws/show/55-12\#Text (дата звернення 22.08.2021 p.)

2. Конституція України: Закон України від 28 червня 1996 року № 254k/96-BP. URL: https://zakon.rada.gov.ua/laws/show/254\%D0\%BA/96\%D0\%B2\%D1\%80\#Text (дата звернення 22.08.2021р.)

3. Про приєднання України до Статуту Ради Європи. Закон України від 31 жовтня 1995 року № 398/95-BP. URL: https://zakon.rada.gov.ua/ laws/show/398/95-\%D0\%B2\%D1\%80\#Text (дата звернення 22.08.2021р.)

4. Про ратиффікацію Конвенції про захист прав людини і основоположних свобод 1950 року, Першого протоколу та протоколів № 2, 4, 7 та 11 до Конвенції № 475/97-вр від 17 липня 1997 р: Закон України від 17 липня 1997 року N 475/97-BP. URL: http://zakon2.rada.gov.ua/laws/ show/475/97-вр. (дата звернення 22.08.2021 р.)

5. Рекомендації Комітету Міністрів Ради Європи R (84) 5 стосовно принципів цивільного судочинства, що направлені на удосконалення судової системи: Прийнято 28.02. 1984 p. URL: https://zakon.rada.gov.ua/ laws/show/994_126 та R (81) 7. (дата звернення 22.08.2021р.) 
6. Рекомендация $\mathrm{R}(81) 7$ Комитета министров государствамчленам относительно путей облегчения доступа к правосудию. Прийнято 14.05.1981. URL: https://zakon.rada.gov.ua/laws/show/994_133\#Text (дата звернення 22.08.2021 р.)

7. Про виконання рішень та застосування практики Європейського суду з прав людини: Закон України від 23 лютого 2006 року N 3477IV. URL: https://zakon.rada.gov.ua/laws/show/3477-15\#Text (дата звернення 22.08.2021 р.)

8. What is the rule of law: Доповнення до Доповіді Генерального секретаря 2014 року про посилення та координацію діяльності Організації Об'єднаних Націй щодо верховенства права.URL: https://www.un.org/ ruleoflaw/what-is-the-rule-of-law/ (дата звернення 22.08.2021р.)

9. Access to Justice: Новини Організації Об'єднаних Націй. URL: https://www.un.org/ruleoflaw/thematic-areas/access-to-justice-and-rule-oflaw-institutions/access-to-justice/ (дата звернення 22.08.2021р.)

10. Sustainable Development Goal 16. Роз'яснення OOH. URL: https://www.un.org/ruleoflaw/sdg-16/ (дата звернення 22.08.2021р.)

11. Володимир Лук'янук. Цей день в історії. URL: https://www.jnsm.com.ua/h/0822Q/ (дата звернення 22.08.2021 p.)

12. Про Цілі сталого розвитку України на період до 2030 року. Указ Президента України від 30 вересня 2019 року№ 722/2019. URL: https://www.president.gov.ua/documents/7222019-29825 (дата звернення 22.08.2021 p.)

13. Угода про асоціацію між Україною, з однієї сторони, та Європейським Союзом, Європейським співтовариством з атомної енергії і їхніми державами-членами, 3 іншої сторони. Ратифіковано Законом України від 16.04.2014 р. № 1678-VII. URL: https://zakon.rada.gov.ua/ laws/show/984_011\#Text (дата звернення 22.08.2021р.)

14. Ізарова І. О., Ханик-Посполітак Р. Ю. Цивільний процес України: Навч. посіб. для студ. юрид. спец. закладів вищої освіти. 3-ге вид. перероб. і доп. Київ : ВД "Дакор", 2019. С. 274

15. Комаров В.В. Про правосуддя в цивільних справах. Курс цивільного процесу. Харків, 2011

16. Про судоустрій і статус суддів. Закон України від 2 червня 2016 р. № 1402-VIII. URL: https://zakon.rada.gov.ua/laws/show/140219\#Text (дата звернення 22.08.2021 р.)

17. UK Government Web Archive. URL:http://www.justice.gov.uk/ courts/procedure-rules/civil/rules (дата звернення 22.08.2021р.)

18. Про виконавче провадження. Закон України від 2 червня 2016 р. № 1404-VIII. URL: https://zakon.rada.gov.ua/laws/show/1404-19/print (дата звернення 22.08.2021р.)

19. Про міжнародне приватне право. Закон України від 23 червня 2005 p. № 2709-IV. URL: https://zakon.rada.gov.ua/laws/show/270915/print (дата звернення 22.08.2021 р.)

20. Кисельова Т. Інтеграція медіації в судову систему України. Підтримка впровадженню судової реформи в Україні. URL: https://rm.coe.int kyselova-t-mediation-integartion-ukr-new-31-07-2017/168075c1e7 (дата звернення 22.08.2021 р.)

21. Єрьоменко Г. Перспективи розвитку медіації в України. URL: https://ukrmediation.com.ua/ua/korysna-informatsiia/materialy/u-vilnomudostupi/1593-Перспективи\%20розвитку\%20медіації\%20в\%20Україні (дата звернення 22.08.2021р.)

22. Тальберг Д.Г. Гражданский иск в уголовном суде или соединенный процесс. э.-орд. проф. Ун-та св. Владимира. Киев: Унив. тип. (В. И. Завадзкого), 1888. С. 224

23. Штутін Я.Л. Лекції з радянського цивільного процесу. Київ. Видво Київ. держ. ун-ту, 1954. С. 128 с.

24. Штутин Я.Л. Право на предьявления иска (по материалам Верховного Суда СССР).Наукові записки. Т. XII. Вип. І. Юридический сборник. № 6. Київ. Вид-во Київ. держ. ун-ту, 1953. С. 85-108;

25. Штутин Я.Л. Предмет доказывания в гражданском процессе. Иркутстк, 1963. С. 39

26. Курилев С.В. Основы теории доказывания в советском правосудии. Москва.С. 333.

27. Штутин Я.Л. Советское гражданское процессуальное право Украины 1917-1920 гг. Проблеми правознавства: Міжвід. наук. зб. Вип. 7. Київ. Вид-во Київ. ун-ту, 1967. С. 163-176.

28. Руда Т. В. Докази і доказування в цивільному процесі України і США: порівняльно-правовий аналіз : автореф. дис. канд. юрид. наук : 12.00.03.Київ. нац. ун-т ім. Тараса Шевченка. Київ. 2012. С. 21

29. Лазько О. М. Засоби доказування у цивільному процесі : автореф. дис. канд. юрид. наук : 12.00.03 . нац. ун-т ім. Тараса Шевченка. Київ, 2013. С. 18.

30. Верещінська І. В. Предмет доказування у справах щодо спадкування: автореф. дис. канд. юрид. наук : 12.00.03. нац. ун-т ім. Тараса Шевченка, Юрид. ф-т. Київ, 2015. С. 18.

31. Шкребець, Д. В. Стадії процесу доказування в цивільному процесі України : автореф. дис. канд. юрид. наук : 12.00.03. Ген. прокуратура України, Нац. акад. прокуратури України.Київ, 2014. С. 16.

32. Бурмак, О. О. Забезпечення доказів у цивільному та нотаріальному процесах : автореф. дис. канд. юрид. наук : 12.00.03. нац. ун-т ім. Тараса Шевченка. Київ, 2015. С. 21.

33. Кучер, Т. М. Теорія доведення у цивілістичному процесі : автореф. дис. д-ра юрид. наук : 12.00.03. нац. ун-т ім. Тараса Шевченка. Київ, 2017. С. 40

34. Захаров П.С. Доказування у справах про відшкодування шкоди, заподіяної внаслідок дорожньо-транспортної пригоди, у цивільному процесі України : авторефр. дис. канд. юрид. наук : 12.00.03. нац. ун-т ім. Тараса Шевченка. Київ, 2019. С. 18.

35. Грабовська О. О. Теоретико-правові проблеми доказування у цивільному процесі України: автореф. дис. д-ра юрид. наук : 12.00.03. нац. ун-т ім. Тараса Шевченка. Київ, 2019. С. 32.

36. Сусло Д. С. Історія суду Радянської України (1917- 1967). Київ. Вид-во Київського ун-ту, 1968. С.33.

37. Заворотько П.П. Процессуальные гарантии исполнения судебного решения. Москва.Юрид.лит. 1974. С.8.

38. Ляшенко, Р. О. Приведення судових рішень у цивільних справах до примусового виконання: автореф. дис. канд. юрид. наук 12.00.03. нац. ун-т ім. Тараса Шевченка. Київ. 2013. С. 19

39. Снідевич О.С. Гласність і відкритість як принципи виконавчого провадження у "Виконавче провадження: теорія та практика : колективна монографія з додатками Р.Ф. Ханової, С.О. Кравцова та ін. Харків: Право.2021. С. 161-173.

40. Малярчук Л.С. Особливості реалізації ухвал суду в контексті ознаки виконавчості: від теорії до практики у "Виконавче провадження: теорія та практика : колективна монографія з додатками. Р.Ф. Ханової, С.О. Кравцова та ін. Харків : Право.2021.С. 231-244.

41. Ізарова І.О., Притика Ю.Д. Як забезпечити ефективне виконання судових рішень: на шляху до сталого правосуддя в Україні у "Виконавче провадження: теорія та практика : колективна монографія з додатками Р.Ф. Ханової, С.О. Кравцова та ін. Харків : Право. 2021, С. 31-42.

42. Штефан М. Й. Цивільний процес: Підручник для юрид. спец. вищих закладів освіти.К. : Ін Юре. Київ 1997. С. 12-15.

43. Штефан М. Й. Цивільне процесуальне право України.Академічний курс; Підруч. для студ. юрид. спец. вищ. навч. закл.Київ. Концерн "Видавничий Дім "Ін Юре", 2005. С. 20.

44. Притика Ю.Д. Киреєва Н.О. Шибіко В.П. Розвиток правничої думки на кафедрі правосуддя. URL: http://visnyk.law.knu.ua/images/ pdf/81_2009.pdf (дата звернення 22.08.2021р.)

45. Чеберяк П. А. Роль судової практики в удосконаленні механізму цівільно-правового регулювання: дис.канд. юрид. наук: 12.00.03. Київський ун-т ім. Т.Г.Шевченка. Київ. 1993. С. 27

46. Захарова О. С. Докази та доказування в справах, що виникають 3 шлюбно-сімейних правовідносин : автореф. дис...канд. юрид. наук: 12.00.03.Киевский ун-т им. Т.Г.Шевченко. Київ. 1995. С. 20 с.

47. Васильев С.В. Особенности судопроизводства по делам о возмещении вреда, причиненного жизни и здоровью гражданина при исполнении им трудовых обязанностей: дис. канд. юрид. наук: 12.00.03. Киевский ун-т им. Тараса Шевченко. Київ. 1996. С. 235

48. Омельченко, Михайло Петрович. Принцип об'єктивної істини цивільного процесуального права України: дис. канд. юрид. наук: 12.00.03. Київський ун-т ім. Тараса Шевченка. Київ. 1996. С. 197.

49. Фурса С. Я. Провадження в справах про встановлення фактів, що мають юридичне значення, у порядку цивільного судочинства : дис. канд. юрид. наук: 12.00.03.. Київський ун-т ім. Т.Шевченка. Київ. 1997. С. 177.

50. Гетманцев О. В. Громадяни як сторони у цивільному процесі Україн: дис. канд. юрид. наук: 12.00.03. Київський ун-т ім. Тараса Шевченка. Київ. 1997. С. 187

51. Снідевич О. С. Позов у цивільних справах, що виникають із земельних правовідносин: автореф. дис. канд. юрид. наук : 12.00.03.. нац. ун-т ім. Т. Шевченка. Київ. 2011. С. 18

52. Шурин О.А. Процесуальні особливості розгляду справ, які виникають у зв'язку із розірванням трудового договору з ініціативи роботодавця: автореф. дис.канд. юрид. наук: 12.00.03.М-во освіти і науки України,Київ. нац. ун-т ім. Тараса Шевченка. Київ, 2017. С. 20.

53. Кармаза О. О. Концепції охорони та захисту житлових прав у цивілістичному процесі: автореф. дис. д-ра юрид. наук : 12.00.03. Київ. нац. ун-т ім. Тараса Шевченка. Київ. 2014. С. 36.

54. Дерій О. О. Аліментні зобов'язання у цивілістичному процесі: автореф. дис. канд. юрид. наук : 12.00.03. Київ. нац. ун-т ім. Тараса Шевченка. Київ. 2014. С. 18.

55. Жорнік М. О. Судочинство в справах про визнання недійсними правочинів, вчинених із дефектами волі (на матеріалах судової практики): автореф. дис. канд. юрид. наук : 12.00.03.Київ. нац. ун-т ім. Тараса Шевченка. Київ. 2015. С. 23.

56. Доманська М. І. Провадження у справах про зміну правового статусу фізичної особи в цивільному процесі України: автореф. дис. канд. юрид. наук : 12.00.03. Київ. нац. ун-т ім. Тараса Шевченка. Київ. 2015. С. 20.

57. Поливач В. О. Особливості розгляду справ, що виникають з кредитних правовідносин в цивільному процесі України: автореф. дис. канд. юрид. наук : 12.00.03. Київ. нац. ун-т ім. Тараса Шевченка. Київ, 2016. С. 20.

58. Круковес В. В. Процесуальні особливості розгляду справ щодо встановлення факту проживання однією сім'єю чоловіка та жінки без шлюбу: автореф. дис. канд. юрид. наук : 12.00.03. Київ. нац. ун-т ім. Тараса Шевченка. Київ. 2018. С. 19.

59. Грабовська О. О. Особливості судочинства в справах про усиновлення (удочеріння) іноземними громадянами дітей, які проживають на території України: автореф. дис. канд. юрид. наук: 12.00.03.Київський національний ун-т ім. Тараса Шевченка. Київ. 2005. С. 19.

60. Кучер, Тетяна Миколаївна. Право на судовий захист в порядку цивільного судочинства України: автореф. дис. канд. юрид. наук : 12.00.03. Київський національний ун-т ім. Тараса Шевченка. Київ. 2009. С. 19. 
61. Лєзін $€$. Є. Забезпечення доказів в цивільному процесі України: автореф. дис канд юрид наук : 12.00.03. Київ. нац ун-т ім. Тараса Шевченка. Київ. 2019. С. 20.

62. Андрійчук О. В. Процесуальні строки у цивільному процесі України : автореф. дис. канд. юрид. наук: 12.00.03.Київ. нац. ун-т ім. Т.Шевченка. Київ. 2009. С. 19.

63. Павлуник І.А. Представництво в цивільному процесі України: Автореф. дис. канд. юрид. наук: 12.00.03. Київ. нац. ун-т ім. Т.Шевченка. Київ. 2002. С. 19

64. Шиманович О.М. Судові постанови у цивільному процесі України (на матеріалі рішень і ухвал суду першої інстанції): Автореф. дис. канд. юрид. наук: 12.00.03.Київ. нац. ун-т ім. Т.Шевченка. Київ. 2005. С. 20.

65. Васильєва-Шаламова, Жанна Віталіївна.Судова експертиза в цивільному процесі: автореф. дис. канд. юрид. наук: 12.00.03. Київський національний ун-т ім. Тараса Шевченка. Київ. 2009. С. 19.

66. Паскар А. Л. Цивільні процесуальні правовідносини: структурно-функціональний аналіз: автореф. дис. канд. юрид. наук: 12.00.03. Київський національний ун-т ім. Тараса Шевченка. Київ. 2009. С. 21.

67. Бондар І.В. Перегляд судових рішень за нововиявленими обставинами: автореф. дис. канд. юрид. наук : 12.00.03. Київ. нац. ун-т ім. Т.Шевченка. Київ. 2009. С. 18 с.

68. Колотілова І. О. Законність та обгрунтованість рішень суду в цивільному процесі України: автореф. дис. канд. юрид. наук : 12.00.03. Київ. нац. ун-т ім. Тараса Шевченка. Київ, 2015. С. 19

69. Ляшенко Н. А. Застосування практики Європейського суду з прав людини при розгляді цивільних справ: автореф. дис. канд. юрид. наук : 12.00.03.Київ. нац. ун-т ім. Тараса Шевченка. Київ, 2017. С. 20.

70. Романюк Я. М. Проблеми застосування цивільно-правових норм у цивільному судочинстві України: автореф. дис. д-ра юрид. наук : 12.00.03. Київ. нац ун-т ім. Тараса Шевченка. Київ. 2017. С. 36.

71. Рибак О. С. Виконання доручень судів іноземних держав у цивільному процесі України: автореф. дис.канд. юрид. наук : 12.00.03. Київ. нац. ун-т ім. Тараса Шевченка. Київ, 2015. С. 19.

72. Войтовський В. С. Касаційне оскарження у цивільному процесі України: автореф. дис.канд. юрид. наук : 12.00.03. Київ. нац. ун-т ім. Тараса Шевченка Київ. 2017. С. 18.

73. Ізарова І.О., Притика Ю.Д. Спрощене позовне провадження иивільного судочинства України: виклики першого року застосування в судовій практиці. Проблеми законності. № 145. 2019. С. 51-67.

74. Ткачук А.О. Зловживання процесуальними правами у цивільному процесі України: дис. доктора фрілософії у галузі права, Київський національний ун-т ім. Тараса Шевченка. Київ. 2020. URL: http://scc.univ.kiev.ua/upload/iblock/959/dis_Ткачук\%20A.O._new.pdf

75. Король Д.А. Диференціація позовного провадження цивільного судочинства: дис. доктора філософії у галузі права, Київський національний ун-т ім. Тараса Шевченка. Київ. 2021. URL: http://scc.univ.kiev.ua/ upload/iblock/194/5uo4k8om1g6urdaufmkewolb9syqxdf6/dis_Король\%20Д..pdf

76. Король О.Д. Принцип співробітництва суду і сторін в цивільному судочинстві. : дис. доктора філософії у галузі права, Київський національний ун-т ім. Тараса Шевченка. Київ. 2021. URL: http://scc.univ.kiev.ua/ upload/iblock/7f7/tf961geluk2j9mfop82f3bily8ctiel1/dis_Король\%200.Д..pdf

77. Спектор О. М. Альтернативні способи вирішення цивільноправових спорів: автореф. дис. канд. юрид. наук: 12.00.03. Київський національний ун-т ім. Тараса Шевченка. Київ. 2012. С. 18

78. Полищук М. Я. Медіація як спосіб вирішення цивільноправових спорів: автореф. дис. канд. юрид. наук: 12.00.03.Київський національний ун-т ім. Тараса Шевченка. Київ. 2017. С. 18

79. Притика Юрій Дмитрович. Теоретичні проблеми захисту прав учасників цивільних правовідносин в третейському суді: автореф. дис. докт. юрид. наук: 12.00 .03 ; Київський національний ун-т ім. Тараса Шевченка. Київ. 2006. С. 33.

80. Ізарова І.О. Теоретичні засади цивільного процесу ЄС : монографрія. Київ.ВД Дакор, 2015. С. 336.

81. Терех О. Альтернативні способи розв'язання трудових спорів: практика України та ЄC. URL: http://visnyk.law.knu.ua/images/articles/ Terekh.pdf (дата звернення 22.08.2021р.)

82. Василина Н.В. Перспективи розвитку інституту врегулювання спору за участю нотаріуса. Вісник Вищої Кваліфікаційної комісії суддів України №1, 2020. С. $20-25$.

83. Васильєва-Шаламова Ж.В. Принцип конфіденційності в медіації: теоретичні проблеми забезпечення. Науково-практичний журнал Підприємництво, господарство і право. 2021. №4. С.10-15.

84. Захарова О.С., СкіченкоА.А., Критерії розмежування судової юрисдикції у справах про захист немайнових прав подружжя. Науковий вісник Міжнародного гуманітарного університету. № 46. 2020. С. 72-76.

85. Кіреєва Н.О., Приймак Є.П. Поняття та правова природа процедури врегулювання спору за участю судді в цивільному процесі України. Науковий вісник Ужгородського національного університету. 2018. Серія ПРАВО. Випуск 48. Том 1. С. 96

Reference

1. Deklaraciya pro derzhavnij suverenitet Ukraïni. Postanova Verhovnoi Radi URSR [Declaration of State Sovereignty of Ukraine. Resolution of the Verkhovna Rada of the USSR] 16.07.1990 № 55-XII. https://zakon.rada.gov.ua/ laws/show/55-12\#Text (in Ukrainian)
2. Konstituciya Ukraïni: Zakon Ukraïni [Constitution of Ukraine] vid 28 chervnya 1996 roku № 254k/96-VR https://zakon rada.gov.ua/laws/ show $/ 254 \% D 0 \% B A / 96-\% D 0 \% B 2 \% D 1 \% 80 \# T e x t$ (in Ukrainian)

3. Pro priednannya Ukraïni do Statutu Radi Evropi. Zakon Ukraïni [On Ukraine's accession to the Statute of the Council of Europe. Law of Ukraine] 31 zhovtnya 1995 roku № 398/95-VR. https://zakon.rada.gov.ua/laws/ show/398/95-\%D0\%B2\%D1\%80\#Text (in Ukrainian)

4. Pro ratifikaciyu Konvenciï pro zahist prav lyudini i osnovopolozhnih svobod 1950 roku, Pershogo protokolu ta protokoliv № 2, 4, 7 ta 11 do Konvenciï № 475/97-vr [Ratification of the Convention for the Protection of Human Rights and Fundamental Freedoms of 1950, the First Protocol and Protocols № 2, 4, 7 and 11 to Convention № 475/97-vr of 17 July 1997: Law of Ukraine]17 lipnya 1997 r: Zakon Ukraïni vid 17 lipnya 1997 roku N 475/97-VR. http://zakon2.rada.gov.ua/laws/show/475/97-vr. (in Ukrainian)

5. Rekomendaciï Komitetu Ministriv Radi Evropi R (84) 5 stosovno principiv civil'nogo sudochinstva, shcho napravleni na udoskonalennya sudovoï sistemi [Recommendation R (84) 5 of the Committee of Ministers of the Council of Europe on the principles of civil procedure aimed at improving the judicial system] 28.02. 1984 r. https://zakon.rada.gov.ua/laws/show/ 994_126 ta R (81) 7. (in Ukrainian)

6. Rekomendaciya $\mathrm{R}(81) 7$ Komiteta ministrov gosudarstvam-chlenam otnositel'no putej oblegcheniya dostupa $k$ pravosudiyu [Recommendation $\mathrm{R}$ (81) 7 of the Committee of Ministers to member states on ways to facilitate access to justice] 14.05.1981. https://zakon.rada.gov.ua/laws/show/994_ 133\#Text (in Ukrainian)

7. Pro vikonannya rishen' ta zastosuvannya praktiki Evropejs'kogo sudu z prav lyudini: Zakon Ukraïn [On the execution of decisions and application of the case law of the European Court of Human Rights: Law of Ukraine] 23 lyutogo 2006 roku N 3477-IV. https://zakon.rada.gov.ua/laws/show/ 3477-15\#Text (in Ukrainian)

8. What is the rule of law: Dopovnennya do Dopovidi General'nogo sekretarya 2014 roku pro posilennya ta koordinaciyu diyal'nosti Organizaciï Ob'€dnanih Nacij shchodo verhovenstva prava. https://www.un.org/ ruleoflaw/what-is-the-rule-of-law/ (in English)

9. Access to Justice: Novini Organizaciï Ob'ednanih Nacij. https://www.un.org/ruleoflaw/thematic-areas/access-to-justice-and-rule-of-lawinstitutions/access-to-justice/ (in English)

10. Sustainable Development Goal 16. Roz'yasnennya OON. https://www.un.org/ruleoflaw/sdg-16/ (in English)

11. Luk'yanuk, V. Cej den' $v$ istoriï [This day in history] https://www.jnsm.com.ua/h/0822Q/ (in Ukrainian)

12. Pro Cili stalogo rozvitku Ukraïni na period do 2030 roku. Ukaz Prezidenta Ukraïni [On the Sustainable Development Goals of Ukraine for the period up to 2030. Decree of the President of Ukraine] 30 veresnya 2019 rokuNo 722/2019. https://www.president.gov.ua/documents/722201929825 (in Ukrainian)

13. Ugoda pro asociaciyu mizh Ukraïnoyu, z odnieï storoni, ta Єvropejs'kim Soyuzom, Єvropejs'kim spivtovaristvom z atomnoï energiï i ïhnimi derzhavami-chlenami, $z$ inshoï storoni [Association Agreement between Ukraine, of the one part, and the European Union, the European Atomic Energy Community and their Member States, of the other part.] Ratifikovano Zakonom Ukraïni vid 16.04.2014 r. № 1678-VII. https://zakon.rada.gov.ua/laws/show/984_011\#Text (in Ukrainian)

14. Izarova, I. O.\& Khanik-Pospolitak, R. YU. Civil'nij proces Ukraïni [Civil process of Ukraine: Textbook.] Navch. posib. dlya stud. yurid. spec. zakladiv vishchoï osviti. 3-ge vid., pererob. i dop. Kï̈v : VD "Dakor", 2019. S. 274 (in Ukrainian).

15. Komarov, V.V. Pro pravosuddya v civil'nih spravah. Kurs civil'nogo procesu [On justice in civil cases. Course of civil proceedings] Kharkiv, 2011. (in Ukrainian)

16. Pro sudoustrij i status suddiv. Zakon Ukraïni [On the judiciary and the status of judges. Law of Ukraine] 2 chervnya 2016 r. № 1402-VIII. https://zakon.rada.gov.ua/laws/show/1402-19\#Text (in Ukrainian)

17. UK Government Web Archive. http://www.justice.gov.uk/courts/ procedure-rules/civil/rules (in English)

18. Pro vikonavche provadzhennya. Zakon Ukraïni [On enforcement proceedings. Law of Ukraine] 2 chervnya 2016 r. № 1404-VIII. https://zakon.rada.gov.ua/laws/show/1404-19/print (in Ukrainian)

19. Pro mizhnarodne privatne pravo. Zakon Ukraïni [On private international law. Law of Ukraine] 23 chervnya 2005 r. № 2709-IV. https://zakon.rada.gov.ua/laws/show/2709-15/print (in Ukrainian)

20. Kisel'ova T. Integraciya mediaciï $v$ sudovu sistemu Ukraïni. Pidtrimka vprovadzhennyu sudovoï reformi v Ukraïni [Integration of mediation into the judicial system of Ukraine. Support for the implementation of judicial reform in Ukraine] https://rm.coe.int/kyselova-t-mediation-integartionukr-new-31-07-2017/168075c1e7 (in Ukrainian)

21. Er'omenko, G. Perspektivi rozvitku mediaciï v Ukraïni [Prospects for the development of mediation in Ukraine] https://ukrmediation.com.ua/ ua/korysna-informatsiia/materialy/u-vilnomu-dostupi/1593-Perspektivi\%20 rozvitku\%20mediaciï\%20v\%20Ukraïni (in Ukrainian)

22. Tal'berg, D.G. Grazhdanskij isk v ugolovnom sude ili soedinennyj process. [Civil action in a criminal court or a joint trial] ord. prof. Un-ta sv. Vladimira. Kiev: Univ. tip. (V. I. Zavadzkogo), 1888. S. 224 (in Russian).

23. Shtutin, YA.L. Lekciï z radyans'kogo civil'nogo procesu [Lectures on the Soviet civil process]. Kiïv. Vid-vo Kiïv. derzh. un-tu, 1954. S. 128 s (in Russian). 
24. Shtutin, YA.L. Pravo na pred'yavleniya iska [he right to sue (according to the Supreme Court of the USSR)] (po materialam Verhovnogo Suda SSSR). Naukovi zapiski. T. HII. Vip. I. YUridicheskij sbornik. № 6. Kiïv. Vidvo Kiïv. derzh. un-tu, 1953. S. 85-108 (in Russian).

25. SHtutin, YA.L. Predmet dokazyvaniya v grazhdanskom processe [The subject of proof in civil proceedings.]. Irkutstk, 1963. S. 39. (in Russian)

26. Kurilev, S.V. Osnovy teorii dokazyvaniya v sovetskom pravosudii [Fundamentals of the theory of proof in Soviet justice]. Moskva.S. 333. (in Russian)

27. Shtutin, YA.L. Sovetskoe grazhdanskoe processual'noe pravo Ukrainy 1917-1920 gg. [Soviet civil procedural law of Ukraine 1917-1920 Problems of jurisprudence: Interdepartmental. Science] Problemi pravoznavstva: Mizhvid. nauk. zb. : Vip. 7. Kiïv. Vid-vo Kiïv. un-tu, 1967. S. 163-176. (in Russian)

28. Ruda, T. V. Dokazi i dokazuvannya v civil'nomu procesi Ukraïni i SSHA: porivnyal'no-pravovij analiz [Evidence and proof in the civil process of Ukraine and the United States: a comparative legal analysis] avtoref. dis. kand. yurid. nauk : 12.00.03.Kiïv. nac. un-t im. Tarasa SHevchenka. Kiïv. 2012, 21 (in Ukrainian).

29. Laz'kot, O. M. Zasobi dokazuvannya u civil'nomu procesi [Means of proof in civil proceedings] avtoref. dis. kand. yurid. nauk : 12.00.03 . nac. unt im. Tarasa SHevchenka. Kiïv, 2013. S. 18(in Ukrainian).

30. Vereshchins'ka, I. V. Predmet dokazuvannya u spravah shchodo spadkuvannya [The subject of proof in cases of inheritance] avtoref. dis. kand. yurid. nauk : 12.00.03. nac. un-t im. Tarasa SHevchenka, YUrid. f-t. Kiïv, 2015. S. 18(in Ukrainian).

31. Shkrebec', D. V. Stadiï procesu dokazuvannya v civil'nomu procesi Ukraini [Stages of the process of proof in the civil process of Ukraine] avtoref. dis. kand. yurid. nauk : 12.00.03. Gen. prokuratura Ukraïni, Nac. akad. prokuraturi Ukraïni.Kiïv, 2014. S. 16(in Ukrainian).

32. Burmak, O. O. Zabezpechennya dokaziv u civil'nomu ta notarial'nomu procesah [Providing evidence in civil and notarial processes] avtoref. dis. kand. yurid. nauk : 12.00.03. nac. un-t im. Tarasa SHevchenka. Kiïv, 2015. S. 21 (in Ukrainian).

33. Kucher, T. M. Teoriya dovedennya u civilistichnomu procesi [Theory of proof in the civil process] avtoref. dis. d-ra yurid. nauk : 12.00.03. nac. un$\mathrm{t}$ im. Tarasa SHevchenka. Kiïv, 2017. S. 40(in Ukrainian).

34. Zaharov, P.S. Dokazuvannya u spravah pro vidshkoduvannya shkodi, zapodiyanoï vnaslidok dorozhn'o-transportnoï prigodi, u civil'nomu procesi Ukraïni [Evidence in cases of compensation for damage caused as a result of a traffic accident in the civil process of Ukraine] avtoref. dis. kand. yurid. nauk : 12.00.03. nac. un-t im. Tarasa SHevchenka. Kiïv, 2019. S. 18 (in Ukrainian)

35. Grabovs'ka, O. O. Teoretiko-pravovi problemi dokazuvannya u civil'nomu procesi Ukraïni: avtoref. dis. d-ra yurid. nauk [Theoretical and legal problems of proof in the civil process of Ukraine] 12.00.03. nac. un-t im. Tarasa SHevchenka. Kiïv, 2019. S. 32(in Ukrainian)

36. Suslo, D. S. Istoriya sudu Radyans'koï Ukraïni (1917- 1967) [History of the Court of Soviet Ukraine (1917- 1967)] Kiïv. Vid-vo Kiïvs'kogo un-tu, 1968. S.33(in Ukrainian).

37. Zavorot'ko, P.P. Processual'nye garantii ispolneniya sudebnogo resheniya [Procedural guarantees of execution of a court decision] Moskva.YUrid.lit. 1974. S.8 (in Russian)

38. Lyashenko, R. O. Privedennya sudovih rishen' u civil'nih spravah do primusovogo vikonannya: avtoref. dis. kand. yurid. nauk [Bringing court decisions in civil cases to enforcement] 12.00.03. nac. un-t im. Tarasa SHevchenka. Kiïv. 2013. S. 19 (in Ukrainian)

39. Snidevich, O.S. Glasnist' i vidkritist' yak principi vikonavchogo provadzhennya [Publicity and openness as principles of enforcement proceedings] u "Vikonavche provadzhennya: teoriya ta praktika [Enforcement proceedings: theory and practice: a collective monograph with appendices] kolektivna monografiya z dodatkami R.F. Hanovoï, S.O. Kravtsova ta in. Harkiv: Pravo.2021.S. 161-173 (in Ukrainian)

40. Malyarchuk, L.S. Osoblivosti realizaciï uhval sudu v konteksti oznaki vikonavchosti: vid teoriï do praktiki [Peculiarities of the implementation of court decisions in the context of the sign of enforcement: from theory to practice] u "Vikonavche provadzhennya: teoriya ta praktika [Enforcement proceedings: theory and practice: a collective monograph with appendices] kolektivna monografiya z dodatkami. R.F. Hanovoï, S.O. Kravtsova ta in. Harkiv : Pravo.2021.S. 231-244 (in Ukrainian).

41. Izarova, I.O. \& Pritika, YU.D. Yak zabezpechiti efektivne vikonannya sudovih rishen': na shlyahu do stalogo pravosuddya v Ukraïni [How to ensure the effective execution of court decisions: on the way to sustainable justice in Ukraine] u "Vikonavche provadzhennya: teoriya ta praktika [Enforcement proceedings: theory and practice: a collective monograph with appendices] kolektivna monografiya z dodatkami R.F. Hanovoï, S.O. Kravtsova ta in. Harkiv : Pravo. 2021, S. 31-42 (in Ukrainian).

42. Shtefan, M. J. Civil'nij process [Civil Procedure] Pidruchnik dlya yurid. spec. vishchih zakladiv osviti.K. : In YUre. Kiïv 1997. S. 12-15 (in Ukrainian).

43. Shtefan, M. J. Civil'ne procesual'ne pravo Ukraïni [Civil procedural law of Ukraine]. Akademichnij kurs; Pidruch. dlya stud. yurid. spec. vishch. navch. zakl.Kiïv. Koncern "Vidavnichij Dim "In YUre", 2005. S. 506 (in Ukrainian).

44. Pritika, YU.D., Kireeva, N.O. \& SHibiko, V.P. Rozvitok pravnichoï dumki na kafedri pravosuddya [Development of legal thought at the Department of Justice.] http://visnyk.law.knu.ua/images/pdf/81_2009.pdf (in Ukrainian)
45. Cheberyak, P. A. Rol' sudovoï praktiki v udoskonalenni mekhanizmu civil'no-pravovogo regulyuvannya [The role of judicial practice in improving the mechanism of civil law regulation] dis.kand. yurid. nauk: 12.00.03.Kiïvs'kij un-t im. T.G.SHevchenka. Kiïv. 1993. S. 27 (in Ukrainian).

46. Zaharova, O. S. Dokazi ta dokazuvannya $v$ spravah, shcho vinikayut' z shlyubno-simejnih pravovidnosin [Evidence and proof in cases arising from marriage and family law] avtoref. dis...kand. yurid. nauk: 12.00.03.Kievskij un-t im. T.G.SHevchenko. Kiïv. 1995. S. 20 s (in Ukrainian).

47. Vasil'ev, S.V. Osobennosti sudoproizvodstva po delam o vozmeshchenii vreda, prichinennogo zhizni i zdorov'yu grazhdanina pri ispolnenii im trudovyh obyazannostej [Peculiarities of court proceedings in cases of compensation for damage caused to the life and health of a citizen in the performance of his duties] dis. kand. yurid. nauk: 12.00.03. Kievskij un-t im. Tarasa Shevchenko. Kiïv. 1996. S. 235(in Russian)

48. Omel'chenko, Mihajlo Petrovich. Princip ob'€ktivnoï istini civil'nogo procesual'nogo prava Ukraïni: dis kand yurid nauk [The principle of objective truth of civil procedural law of Ukraine] 12.00.03. Kiïvs'kij un-t im. Tarasa Shevchenka. Kiïv. 1996. S. 197 (in Ukrainian)

49. Fursa, S. YA. Provadzhennya v spravah pro vstanovlennya faktiv, shcho mayut' yuridichne znachennya, u poryadku civil'nogo sudochinstva [Proceedings in cases of establishing facts of legal significance, in the order of civil proceeding] dis. kand. yurid. nauk: 12.00.03.. Kiïvs'kij un-t im. T.SHevchenka. Kiïv. 1997. S. 177 (in Ukrainian).

50. Getmancev, O. V. Gromadyani yak storoni u civil'nomu procesi Ukraïn [Citizens as parties in the civil process of Ukraine] dis. kand. yurid. nauk: 12.00.03. Kiïvs'kij un-t im. Tarasa SHevchenka. Kiïv. 1997. S. 187 (in Ukrainian).

51. Snidevich, O. S. Pozov u civil'nih spravah, shcho vinikayut' iz zemel'nih pravovidnosin: avtoref. dis. kand. yurid. nauk [Claim in civil cases arising from land relations] 12.00.03.. nac. un-t im. T. SHevchenka. Kiïv. 2011. s. 18(in Ukrainian).

52. Shurin, O.A. Procesual'ni osoblivosti rozglyadu sprav, yaki vinikayut' u zv'yazku iz rozirvannyam trudovogo dogovoru z iniciativi robotodavcya [Procedural features of consideration of cases that arise in connection with the termination of the employment contract at the initiative of the employer] avtoref. dis.kand. yurid. nauk: 12.00.03.M-vo osviti i nauki Ukraïni, Kiïv. nac. un-t im. Tarasa SHevchenka. Kiï, 2017. S. 20 (in Ukrainian).

53. Karmaza, O. O. Koncepciï ohoroni ta zahistu zhitlovih prav u civilistichnomu procesi [Concepts of protection and protection of housing rights in the civil process] avtoref. dis. d-ra yurid. nauk : 12.00.03. Kiïv. nac. un-t im. Tarasa SHevchenka. Kiïv. 2014. S. 36(in Ukrainian).

54. Derij, O. O. Alimentni zobov'yazannya u civilistichnomu procesi: avtoref. dis. kand. yurid. nauk [Alimony obligations in the civil process] 12.00.03. Kiïv. nac. un-t im. Tarasa SHevchenka. Kiïv. 2014. S. 18 (in Ukrainian)

55. ZHornik, M. O. Sudochinstvo $v$ spravah pro viznannya nedijsnimi pravochiniv, vchinenih iz defektami voli (na materialah sudovoï praktiki) [Judicial proceedings in cases of invalidation of transactions committed with defects of will (on the materials of judicial practice)] avtoref. dis. kand. yurid. nauk : 12.00.03.Kiïv. nac. un-t im. Tarasa SHevchenka. Kiïv. 2015. S. 23 (in Ukrainian).

56. Domans'ka, M. I. Provadzhennya u spravah pro zminu pravovogo statusu fizichnoï osobi v civil'nomu procesi Ukraïni [Proceedings in cases of changing the legal status of an individual in the civil process of Ukraine] avtoref. dis. kand. yurid. nauk : 12.00.03. Kiïv. nac. un-t im. Tarasa SHevchenka. Kiïv. 2015. S. 20(in Ukrainian).

57. Polivach, V. O. Osoblivosti rozglyadu sprav, shcho vinikayut' z kreditnih pravovidnosin $v$ civil'nomu procesi Ukraïni [Peculiarities of consideration of cases arising from credit relations in the civil process of Ukraine] avtoref. dis. kand. yurid. nauk : 12.00.03. Kiïv. nac. un-t im. Tarasa SHevchenka. Kiïv, 2016. S. 20(in Ukrainian).

58. Krukovetc, V. V. Procesual'ni osoblivosti rozglyadu sprav shchodo vstanovlennya faktu prozhivannya odnieyu sim'єyu cholovika ta zhinki bez shlyubu [Procedural features of consideration of cases concerning establishment of the fact of living by one family of the man and the woman without marriage] avtoref. dis. kand. yurid. nauk : 12.00.03. Kiïv. nac. un-t im. Tarasa SHevchenka. Kiïv. 2018. S. 19 (in Ukrainian)

59. Grabovs'ka, O. O. Osoblivosti sudochinstva v spravah pro usinovlennya (udocherinnya) inozemnimi gromadyanami ditej, yaki prozhivayut' na teritorii Ukraïni [Peculiarities of judicial proceedings in cases of adoption (adoption) by foreign citizens of children living in Ukraine] avtoref. dis. kand. yurid. nauk: 12.00.03.Kiïvs'kij nacional'nij un-t im. Tarasa SHevchenka. Kiïv. 2005. S. 19(in Ukrainian)

60. Kucher, T. M. Pravo na sudovij zahist v poryadku civil'nogo sudochinstva Ukraini [The right to judicial protection in the order of civil proceedings of Ukraine] avtoref. dis. kand. yurid. nauk : 12.00.03.Kiïvs'kij nacional'nij un-t im. Tarasa SHevchenka. Kiïv. 2009. S. 19(in Ukrainian).

61. L€zin, $€$. $€$. Zabezpechennya dokaziv v civil'nomu procesi Ukraïni [Providing evidence in the civil process of Ukraine] avtoref. dis. kand. yurid. nauk : 12.00.03. Kiïv. nac. un-t im. Tarasa SHevchenka. Kiïv. 2019. S. 20 (in Ukrainian).

62. Andrijchuk, O. V. Procesual'ni stroki u civil'nomu procesi Ukraïni [Procedural terms in the civil process of Ukraine] avtoref. dis. kand. yurid. nauk: 12.00.03.Kiïv. nac. un-t im. T.SHevchenka. Kiïv. 2009. S. 19 (in Ukrainian). 
63. Pavlunik, I.A. Predstavnictvo v civil'nomu procesi Ukraïni [Representation in the civil process of Ukraine] Avtoref dis. kand yurid nauk: 12.00.03. Kiïv. nac. un-t im. T.SHevchenka. Kiïv. 2002. S. 19(in Ukrainian)

64. SHimanovich, O.M. Sudovi postanovi u civil'nomu procesi Ukraïni (na materiali rishen' i uhval sudu pershoï instanciï) [Judicial decisions in civil proceedings of Ukraine (on the material of decisions and rulings of the court of first instance)] Avtoref. dis. kand. yurid. nauk: 12.00.03.Kiïv. nac. un-t im. T.SHevchenka. Kiïv. 2005. S. 20 (in Ukrainian).

65. Vasil'eva-SHalamova, Z. V. Sudova ekspertiza v civil'nomu procesi: avtoref dis kand. yurid nauk [Forensic examination in civil proceedings] 12.00.03. Kiïvs'kij nacional'nij un-t im. Tarasa SHevchenka. Kiïv. 2009. S. 19 (in Ukrainian).

66. Paskar, A. L. Civil'ni procesual'ni pravovidnosini: strukturnofunkcional'nij analiz [Civil procedural legal relations: structural and functional analysis] avtoref. dis. kand. yurid. nauk: 12.00.03. Kiïvs'kij nacional'nij un-t im. Tarasa SHevchenka. Kiïv. 2009. S. 21 (in Ukrainian).

67. Bondar, I.V. Pereglyad sudovih rishen' za novoviyavlenimi obstavinami: avtoref. dis. kand. yurid. nauk [Review of court decisions on newly discovered circumstances] 12.00.03. Kiïv. nac. un-t im. T.SHevchenka. Kiïv. 2009. S. 18 s. (in Ukrainian).

68. Kolotilova, I. O. Zakonnist' ta obgruntovanist' rishen' sudu v civil'nomu procesi Ukraïni [Legality and validity of court decisions in the civil process of Ukraine] avtoref. dis. kand. yurid. nauk: 12.00.03. Kiïv. nac. un-t im. Tarasa SHevchenka. Kiïv, 2015. S. 19 (in Ukrainian)

69. Lyashenko, N. A. Zastosuvannya praktiki €vropejs'kogo sudu z prav lyudini pri rozglyadi civil'nih sprav [Application of the practice of the European Court of Human Rights in civil cases] avtoref. dis. kand. yurid. nauk : 12.00.03.Kiïv. nac. un-t im. Tarasa SHevchenka. Kiïv, 2017. S. 20 (in Ukrainian).

70. Romanyuk, YA. M. Problemi zastosuvannya civil'no-pravovih norm u civil'nomu sudochinstvi Ukraïni [Problems of application of civil law norms in civil proceedings of Ukraine] avtoref. dis. d-ra yurid. nauk : 12.00.03. Kiïv. nac. un-t im. Tarasa SHevchenka. Kiïv. 2017. S. 36 (in Ukrainian).

71. Ribak, O. S. Vikonannya doruchen' sudiv inozemnih derzhav u civil'nomu procesi Ukraïni [Execution of orders of courts of foreign states in the civil process of Ukraine] avtoref. dis.kand. yurid. nauk: 12.00.03. Kiïv. nac. un-t im. Tarasa SHevchenka. Kiïv, 2015.S. 19 (in Ukrainian).

72. Vojtovs'kij, V. S. Kasacijne oskarzhennya u civil'nomu procesi Ukraïn [Cassation appeal in the civil process of Ukraine] avtoref. dis.kand. yurid. nauk : 12.00.03. Kiïv. nac. un-t im. Tarasa SHevchenka Kiïv. 2017. S. 18(in Ukrainian)

73. Izarova, I.O. \& Pritika, YU.D. Sproshchene pozovne provadzhennya civil'nogo sudochinstva Ukraïni: vikliki pershogo roku zastosuvannya v sudovij praktici [Simplified litigation of civil proceedings in Ukraine: the challenges of the first year of application in judicial practice] Problemi zakonnosti. № 145. 2019. S. 51-67 (in Ukrainian).

74. A Tkachuk, A.O. Zlovzhivanniz processual'nimy pravamy u civilnomy processi Ukrainy [buse of procedural rights in the civil process of Ukraine] dis. doktora philosophii u galuzi prava, Kiïvs'kij nacional'nij un-t im. Tarasa Shevchenka. Kiïv. Kiïv. 2020. http://scc.univ.kiev.ua/upload/iblock/ 959/dis_Ткачук\%20A.O._new.pdf (in Ukrainian)

75. Korol', D.A. Differenziatia pozovnogo provadgennia civilnogo sudochinsnva [Differentiation of claim proceedings in civil proceedings] dis. doktora philosophii u galuzi prava, Kiïvs'kij nacional'nij un-t im. Tarasa SHevchenka. Kiïv. Kiïv. 2021. http://scc.univ.kiev.ua/upload/iblock/194/5uo4k 8om1g6urdaufmkewolb9syqxdf6/dis_Король\%20Д..pdf (in Ukrainian)

Yu. Prytyka, Dr. Sc. (Law), Prof.,

I. Izarova, Dr. Sc. (Law), Prof.

Taras Shevchenko National University of Kyiv, Kyiv, Ukraine
76. Korol', O.D. Princip spivrobitniznva sudu ta storin u civilnome sudochinstvi [The principle of cooperation between the court and the parties in civil proceedings] dis. doktora philosophii u galuzi prava, Kiïvs'kij nacional'nij un-t im. Tarasa SHevchenka. Kiïv. 2021. http://scc.univ.kiev.ua/ upload/iblock/7f7/tf961geluk2j9mfop82f3bily8ctiel1/dis_Король\%200.Д..pdf (in Ukrainian)

77. Spektor, O. M. Al'ternativni sposobi virishennya civil'no-pravovih sporiv [Alternative ways of resolving civil disputes] avtoref. dis. kand. yurid. nauk: 12.00.03 .Kiïvs'kij nacional'nij un-t im. Tarasa SHevchenka. Kiïv. 2012. S. 18 (in Ukrainian).

78. Polishchuk, M. YA. Mediaciya yak sposib virishennya civil'nopravovih sporiv [Mediation as a way to resolve civil disputes] avtoref. dis. kand. yurid. nauk: 12.00.03.Kiïvs'kij nacional'nij un-t im. Tarasa SHevchenka. Kiïv. 2017. S. 18 (in Ukrainian).

79. Prytyka, Yu. D. Teoretichni problemi zahistu prav uchasnikiv civil'nih pravovidnosin $v$ tretejs'komu sudi [Theoretical problems of protection of the rights of participants of civil legal relations in arbitration court] avtoref. dis. dokt. yurid. nauk: 12.00.03 ; Kiïvs'kij nacional'nij un-t im. Tarasa SHevchenka. Kiïv. 2006. S. 33 (in Ukrainian)

80. Izarova, I.O. Teoretichni zasadi civil'nogo procesu $\in S$ [Theoretical foundations of the EU civil process] monografiya. Kiïv.VD Dakor, 2015. S. 336 (in Ukrainian).

81. Terekh, O. Alternativny sposoby rosviazannia trudovyh spori: praktyka Ukrainy na ES [Alternative ways of resolving labor disputes: the practice of Ukraine and the EU] http://visnyk.law.knu.ua/images/articles/ Terekh.pdf (in Ukrainian)

82. Vasilina, N.V. Perspektivi rozvitku institutu vregulyuvannya sporu za uchastyu notariusa [rospects for the development of the institution of dispute resolution with the participation of a notary] Visnik Vishchoï Kvalifikacijnoi komisiï suddiv Ukraïni №1, 2020. S.20 - 25 (in Ukrainian).

83. Vasil'€va-SHalamova, ZH.V. Princip konfidencijnosti $v$ mediacii: teoretichni problemi zabezpechennya [The principle of confidentiality in mediation: theoretical problems of security] Naukovo-praktichnij zhurnal Pidpriemnictvo, gospodarstvo i pravo. 2021. №4. S.10-15 (in Ukrainian).

84. Zaharova, O.S. \& Skichenko, A.A., Kriteriï rozmezhuvannya sudovoï yurisdikciï u spravah pro zahist nemajnovih prav podruzhzhya [Criteria for delimitation of judicial jurisdiction in cases of protection of nonproperty rights of spouses] Naukovij visnik Mizhnarodnogo gumanitarnogo universitetu. № 46. 2020. S. 72-76 (in Ukrainian).

85. Kire€va, N.O. \& Prijmak, Є.P. Ponyattya ta pravova priroda proceduri vregulyuvannya sporu za uchastyu suddi $v$ civil'nomu procesi Ukraïni [The concept and legal nature of the dispute resolution procedure with the participation of a judge in the civil proceedings of Ukraine] Naukovij visnik Uzhgorods'kogo nacional'nogo universitetu. 2018. Seriya PRAVO. Vipusk 48. Tom 1. S.96 (in Ukrainian).

Received: $31 / 07 / 2021$ Accepted: $20 / 08 / 2021$

\section{FORMATION OF THE NATIONAL DOCTRINE OF CIVIL PROCEDURE IN THE WORKS OF SCIENTISTS OF KYIV UNIVERSITY WITHIN UKRAINE'S INDEPENDENCE PERIOD}

The event of the thirtieth anniversary of Ukraine's independence [1] provides an excellent opportunity to sum up the interim results, analyse the achievements made in building an independent democracy, as well as to understand the miscalculations that can hardly be avoided. Legal science plays a huge role in this, particularly, its part related to the field of administration of justice in civil cases which is ensuring the effective settlement of civil disputes and the administration of civil justice. In view of this, the purpose of the study is to establish the contribution of legal scholars of Taras Shevchenko National University of Kyiv in the development of the doctrine of the science of civil procedural law during the period of independence of Ukraine since 1991. To achieve this goal, scientific methods of analysis of the main legislative acts regulating civil procedural relations were used, the provisions of those studies were singled out and characterized; the latter proposed new approaches to improving the mechanism of exercising the right to a fair trial, ensuring access to justice in civil cases; development and improvement of civil justice in the context of modern international, in particular, European approaches. The results of the study revealed more than forty dissertation researches, which were promoted during the selected period at the University, as well as a number of scientific studies that significantly influenced the development of the national tradition of civil procedure. The conclusions summarize the results of the study and identify areas for further development of research in the field of civil procedural law of Ukraine. In particular, it is noted that today special attention should be paid to the need for proper implementation in Ukraine of the concept of the right of everyone to a fair trial, guaranteed by the European Convention, as well as to increase out-of-court settlement of disputes mediating the right to access and freedoms in the modern world. It is important to understand the global trend of reconciliation of the parties as the most effective settlement of disputes and the spread of various ways that allow the parties to find the most convenient and effective way to protect their rights.

Keywords: civil process, Ukraine, access to justice, legal doctrine, Kyiv University, Civil Procedure Code of Ukraine. 
Bulletin of Taras Shevchenko National University of Kyiv. Legal Studies, 2021; 3 (118): 106-112

удК 351(477)

DOI: https:doi.org/10.17721/1728-2195/2021/3.118-19
ISSN 1728-2195

(C) Taras Shevchenko National University of Kyiv, Publishing center "Kyiv University", 2021

Кӥ̈ С. Проневич, д-р юрид. наук., проф. Київський національний університет імені Тараса Шевченка, Київ, Україна ORCID ID: 0000-0001-5170-4751

\title{
ІНСТИТУТ РАДНИКА У ВІТЧИЗНЯНІЙ СИСТЕМІ ПУБЛІЧНОЇ СЛУЖБИ: СТАН I ПРОБЛЕМИ ЛЕГАЛЬНОГО ЗАКРІПЛЕННЯ
}

\begin{abstract}
Статтю присвячено осмисленню специфіки соціальної місії і стану легального закріплення адміністративної правосуб'єктності радників в органах державної влади й органах місцевого самоврядування. Установлено, що ангажемент кандидатів на посади радників здійснюється у контексті забезпечення наукового супроводу формування і реалізації державної політики, імплементації кращих управлінських практик, пошуку оптимальних управлінсько-правових алгоритмів вирішення колізій, підвищення якості підготовки управлінських рішень суб'єктами владних повноважень. Констатовано необхідність новелізації вітчизняного службового законодавства з метою конкретизації функцій, основних завдань і повноважень радників, артикуляції базових кваліфікаційних вимог до кандидатів на посади радників, чіткого визначення правових основ взаємодії радників із кар'єрними публічними службовцями та комунікації з інститутами громадянського суспільства, артикуляції морально-етичних імперативів службової діяльності радників.
\end{abstract}

Ключові слова: публічна служба, патронатна служба, радник в органах державної влади й органах місцевого самоврядування, штатний радник, радник на громадських засадах.

\section{ВСТУП}

Тяглість державницької ідеї й осмислене прагнення до свободи є важливими маркерами української ідентичності. Багато поколінь українців прагнули до самовизначення у межах етнічних теренів. Масштабні національновизвольні змагання у різні історичні епохи незмінно мали за основну мету звільнення від іноземного гніту та закладення підвалин власної держави. Щоразу українці змушені були долати потужний тиск військовокарального апарату держав-поневолювачів, кревно зацікавлених у колонізації території, викоріненні будь-яких проявів українства та манкуртизації національних духовних лідерів. Навіть в умовах смертельної загрози та невимовної скрути за радянських часів незламна воля i життєві сили українського народу були збережені, що стало запорукою для національного відродження і відновлення держави. Акт проголошення незалежності України від 24 серпня 1991 року став політико-правовою основою створення самостійної Української держави. Природно, що ґрунтована на приматі інтересів держави та пріоритетизації використання імперативного методу у державному управлінні постколоніальна адміністрація була неспроможна забезпечити ствердження ліберальних цінностей і дотримання суб'єктивних прав приватних осіб. Лише останнім часом започатковано імплементацію європейських стандартів належного врядування у контексті розбудови людиноцентричної та інклюзивної системи публічного адміністрування. Безперечно, її стрижнем $€$ публічна служба, що у широкому сенсі тлумачиться громадянським суспільством як "почесний обов'язок шляхетних людей". Перегляд соціальної місії публічних службовців, забезпечення належної реалізації легального публічного інтересу, перезавантаження бюрократичного апарату та апробація нових підходів до розв'язання проблем у публічному секторі потребує сучасного науково-аналітичного супроводу. Важливим інтелектуальним і креативним компонентом публічної служби $€$ інститут радників керівників органів публічної влади.

Ангажемент кваліфікованих представників фрахового/експертного середовища на посади радників в органах державної влади й органах місцевого самоврядування традиційно розглядається крізь призму підвищення якості нормотворчої діяльності та прийняття збалансованих адміністративно-управлінських рішень уповноваженими суб'єктами владних повноважень, налагодження ефективної комунікації і партнерської взаємодії органів публічної влади з масмедіа та громадськістю. Водночас недостатня визначеність правового статусу радників, розмитість їхнього "функціоналу" та відсутність чітких критеріїв оцінювання ефрективності службової діяльності привертає увагу широкого загалу до цього службово-правового інституту. У суспільстві діяльність радників нерідко тлумачиться упереджено-негативно. Як наслідок, радники асоціюються 3 "другим ешелоном влади/неформальним інститутом публічної влади", "безвідповідальним оточенням високопосадовців", "привілейованою управлінською кастою", "інструментом латентного впливу на прийняття управлінських рішень", "сполучною ланкою між керівниками і лобістським середовищем" або ж навіть "делікатною матерією, через яку здійснюється корупційний вплив". У середовищі кар'єрних публічних службовців радники часто сприймаються з недовірою, що зумовлено поляризацією політичної і кар'єрної компонент публічної служби, поширеним сприйняттям радників як "чужорідних зовнішніх креатур" та "елементів фаворитизації публічної служби", існуванням потенційної загрози політично мотивованого втручання радників у публічно-владну управлінську діяльність державних службовців та/або посадових осіб місцевого самоврядування. Окремі масмедіа апріорно прагнуть до епатажного висвітлення діяльності радників, акцентуючи увагу на безсистемному характері кадрової селекції без урахування "фахового бекграунду" кандидатів, їх "придворному" статусі, залежності від "прихильності патрона", необхідності "витончено маневрувати", "компліментарно реагувати", приреченості зберігати "високу довіру" та перманентно підтверджувати власну лояльність. Зауважимо, що певні підстави для конструктивної критики існують, оскільки радники часто демонструють низький фаховий рівень і політичну заангажованість, а також сприяють просуванню корпоративних інтересів окремих лобістських груп. Зазначене вище свідчить про необхідність комплексного аналізу специфіки легального закріплення інституту радників у системі публічної служби, з'ясування особливостей їхньої адміністративної правосуб'єктності.

Аналіз останніх досліджень і публікацій. Окремі аспекти правового статусу радників органів публічної влади/посадових осіб та особливості організації їхньої службової діяльності традиційно висвітлюються публіцистами і громадськими діячами. Натомість у вітчизняній адміністративно-правовій науці проблема функціонування інституту радника розглядається спорадично й побіжно, переважно крізь призму осмислення соціально-правового феномену патронатної служби (Н. В. Бондаренко [1], О.І. Костилєв [2], Г.Д. Стратієнко [3], В. В. Чорна [4] та ін.). Об'єктивним наслідком ухвали Закону України "Про державну службу" від 10 грудня 2015 року стала архаїзація значної частини наукового доробку попе- 